University of Nebraska - Lincoln

DigitalCommons@University of Nebraska - Lincoln

Virology Papers

Virology, Nebraska Center for

2005

\title{
Epidemiological Characteristics of Human Herpesvirus-8 Infection in a Large Population of Antenatal Women in Zambia
}

W. Klaskala

Roche Laboratories

B. P. Brayfield

University of Nebraska-Lincoln

C. Kankasa

University of Zambia

G. Bhat

University of Zambia

J. T. West

University of Nebraska-Lincoln, jwest2@unl.edu

See next page for additional authors

Follow this and additional works at: https://digitalcommons.unl.edu/virologypub

Part of the Virology Commons

Klaskala, W.; Brayfield, B. P.; Kankasa, C.; Bhat, G.; West, J. T.; Mitchell, C. D.; and Wood, Charles, "Epidemiological Characteristics of Human Herpesvirus-8 Infection in a Large Population of Antenatal Women in Zambia" (2005). Virology Papers. 144.

https://digitalcommons.unl.edu/virologypub/144

This Article is brought to you for free and open access by the Virology, Nebraska Center for at DigitalCommons@University of Nebraska - Lincoln. It has been accepted for inclusion in Virology Papers by an authorized administrator of DigitalCommons@University of Nebraska - Lincoln. 


\section{Authors}

W. Klaskala, B. P. Brayfield, C. Kankasa, G. Bhat, J. T. West, C. D. Mitchell, and Charles Wood 
Published in the Journal of Medical Virology (2005)75: 93-100. DOI: 10.1002/jmv.20242

Copyright 2005, Wiley-Liss. Accepted September 21, 2004. Used by permission.

\title{
Epidemiological Characteristics of Human Herpesvirus-8 Infection in a Large Population of Antenatal Women in Zambia
}

\author{
W. Klaskala ${ }^{1,4}$, B.P. Brayfield ${ }^{1}$, C. Kankasa ${ }^{2}$, G. Bhat ${ }^{2}$, J. T. West ${ }^{1}$, C. D. Mitchell ${ }^{3}$, \\ and Charles Wood ${ }^{1, *}$
}

${ }^{1}$ University of Nebraska-Lincoln, Nebraska Center for Virology and the School of Biological Sciences, Lincoln, Neb.

${ }^{2}$ University of Zambia, School of Medicine and University Teaching Hospital, Zambia

${ }^{3}$ University of Miami, School of Medicine, Miami, Florida

${ }^{4}$ Roche Laboratories, Inc., Nutley, New Jersey

*Correspondence to: Charles Wood, cwood1@unl.edu.

Comprehensive data describing epidemiological characteristics of the human herpesvirus- 8 or Kaposi's sarcoma-associated herpesvirus (HHV-8 or KSHV) infection among pregnant women in a central sub-Saharan Africa are not available. This study determined virus prevalence estimates and the risk factors associated with HHV-8 infection. Crosssectional, enrollment visit data were analyzed from a prospective cohort study of perinatal transmission of HHV-8 in Lusaka, Zambia. Exposure data were obtained via structured interview, physical examination, medical chart review, and laboratory testing. Among 3,160 antenatal women serologically screened for HHV-8 between September 1998 and October 2000, 40.2\% were seropositive. The HHV-8 positive women were more likely to be co-infected with HIV-1 than those who were HHV-8 negative ( $34 \%$ vs. $26 \%$; $P<0.0001)$. Of 154 variables evaluated by logistic regression analyses, only three risk factors, have emerged as independent predictors of HHV-8 positive serology: diagnosis of genital warts, HIV-1 co-infection and primary education. The association of HHV-8 infection with genital warts and HIV-1 co-infection suggests heterosexual transmission of HHV-8. HIV-1 infection may also act as a marker for particular behaviors, which could be sexual in nature, that are associated with both HIV-1 and HHV-8 transmission. Since HHV-8 facilitates development of AIDS-related Kaposi's sarcoma (KS), the results of this study could be utilized to identify specific population groups of pregnant women who are at increased risk for this disease.

Key words: HHV-8 infection; HIV-1 infection; prevalence; risk assessment; pregnant women; Zambia.

Grant sponsor: PHS; Grant numbers: CA75903, CA76958; Grant sponsor: Fogarty International Training; Grant number: TW01492; Grant sponsor: NCRR COBRE (to CW); Grant number: RR 15635; Grant sponsor: Fogarty International Center; Grant number: D43 TW 00002.

\section{Introduction}

Human herpesvirus-8 (HHV-8), also known as Kaposi's sarcoma-associated herpesvirus (KSHV), is considered the casual agent of Kaposi's sarcoma (KS), the most common cancer related to acquired immunodeficiency syndrome (AIDS) in many African countries including Zambia [Moore and Chang, 1995; Newton et al., 2003a]. The worldwide prevalence and risk factors of HHV-8 infection vary geographically and across population groups. In North America and Northern/Western Europe, infection is rare, not exceeding 5\% among healthy blood donors [Gao et al., 1996; Whitby et al., 1998]. In KS endemic areas, such as Greece, Southern Italy, and subSaharan Africa, prevalence of the virus is much higher, particularly among population groups such as elderly men [Cattani et al., 2003]. In recent years, studies conducted in Africa reported HHV-8 seropositivity between $32 \%$ and $100 \%$ in adult populations [Bestetti et al., 1998; He et al., 1998; Olsen et al., 1998; Enbom et al., 1999; Sitas et al., 1999; Serraino et al., 2001; Baeten et al., 2002; DeSantis et al., 2002; Lavreys et al., 2003; Mbulaiteye et al., 2003; Newton et al., 2003b]. However, reports from the central sub-Saharan region on HHV-8 prevalence and associated risk factors are limited and typically based on convenient sampling methods and small numbers of study participants. This is mainly due to lack of routine screening for this virus. In sub-Saharan countries such as Zambia, a large percentage of women and children diagnosed with 
HHV-8 and/or KS are co-infected with HIV-1, suggesting that HIV-1 infection could somehow be related to HHV-8 infection [Athale et al., 1995; He et al., 1998; Eltom et al., 2002; Newton et al., 2003a]. Although a higher prevalence of HHV-8 has been documented in HIV-1 infected individuals than in the healthy general population [Nuvor et al., 2001; Eltom et al., 2002; Hladik et al., 2003], the role of HHV-8 in facilitating HIV-1 infection requires further investigation [Moore and Chang, 1995; Newton et al., 2003a]. Various studies have suggested that both sexual [Martin et al., 1998; Sosa et al., 1998; Grulich et al., 1999; Rezza et al., 2000; Baeten et al., 2002] and nonsexual [Blauvelt et al., 1997; Whitby et al., 1998; Andreoni et al., 1999; Mantina et al., 2001] modes of transmission are correlated with HHV-8 seropositivity. Prior epidemiological reports have indicated that certain high-risk sexual practices (e.g., anal intercourse) [Melbye et al., 1998; Regamey et al., 1998; Eltom et al., 2002; Renwick et al., 2002], work as a commercial sex worker or prostitute [Sosa et al., 1998; Challine et al., 2001; Eltom et al., 2002; de Sanjose et al., 2002], coinfection with other pathogens such as HIV-1, HBV, and HCV [Sosa et al., 2001; Lavreys et al., 2003; Newton et al., 2003a], intravenous drug use and exposure to blood products [Cannon et al., 2001; Sosa et al., 2001; Hladik et al., 2003], or oral secretions including saliva [Blauvelt et al., 1997; Blackbourn et al., 1998; Pauk et al., 2000] are also associated with HHV-8 seropositivity.

To examine HHV-8 seroepidemiology and associated risk factors, we analyzed data collected prospectively on a large population of antenatal Zambian women. Identification of risk determinants for HHV-8 among African antenatal women may provide some insight on possible routes of virus transmission in this population.

\section{Materials and Methods \\ Design and Study Population}

In this study, we report the findings from analyses of cross-sectional data and enrollment visit data from a prospective cohort study on pathogenesis and transmission of HHV-8 infection. The study objective was to determine seroprevalence estimates and associated risk factors for HHV-8. The local Research and Ethics Review Committee of the University Teaching Hospital (UTH), Lusaka, Zambia and the Zambian Ministry of Health approved the study protocols.

The study took place in Zambia, a central sub-Saharan African countrywith an estimated population of 9 million. A total of 3,160 women were recruited to participate in the study at UTH, the largest tertiary care institution in the country and the main referral center for Lusaka, the capital of the country. As the referral center of Lusaka, approximately $20 \%$ of women admitted annually are referred to UTH for special care such as multiple pregnancy, Caesarean section, severe anemia, young age, hypertension, tuberculosis, malaria, or other opportunistic infections including AIDS. Between September 1998 and
October 2000, women admitted to the labor ward were approached for enrollment in the study. Those who were clinically diagnosed with KS, AIDS, TB, malaria, or cancer or had any other health conditions that might have affected their immune systems were not eligible to participate in the study. In addition, women had to reside in the metropolitan area of Lusaka. Disease histories as well as physical examinations were carried out to rule out any clinical symptoms or visible signs for these conditions.

\section{Data Collection}

All study subjects signed informed consent and were evaluated by study clinicians. A set of pre-tested, standardized questionnaires was used to gather data. All personal identifiers were removed to ensure patient confidentiality. Medical history information were retrospectively retrieved, with patients' permission, from hospital medical records.

A total of 154 variables were identified and assessed in this study. Data were collected on seven domains of interest that included the following: (1) socio-demographics (age, tribal identity, education, marital status, religion, occupation, and household income); (2) current medical status (weight, diagnosis of tuberculosis, and diagnosis of specific ulcerative and non-ulcerative STDs); (3) medical history (histories of blood transfusion, hypertension, drug abuse, and use of antibiotics in past 12 months); (4) reproductive and obstetric history (number and outcomes of pregnancies, use of family planning and birth control methods including condoms); (5) sexually transmitted disease history (histories of STDs, genital ulceration, vaginal discharge, and cancer including cervical dysplasia); (6) sexual behavior history (age at first sexual encounter, steady partner in past 3 years, new partners in past 3 years, sex with partner with penile lesion, sex under influence of alcohol, anal intercourse, being raped, practice of dry sex, and use of herbs vaginally; and (7) laboratory test results (results of serological testing for HHV-8, HIV-1, and syphilis).

\section{Laboratory Testing}

Blood specimens were collected by venipuncture into acid citrate dextrose tubes and processed using centrifugation at the on-site study laboratory within $6 \mathrm{hr}$ of being drawn. The separated plasma was frozen at 208C and the blood cells at $808 \mathrm{C}$. All specimens were then shipped to the Nebraska Center for Virology at the University of Nebraska-Lincoln (UNL) for serological testing.

Plasma was tested for HHV-8 antibodies by indirect IFA using HHV-8 infected BC-3 cells, an HHV-8 positive and an Epstein-Barr virus (EBV) negative B-cell lymphoma cell line as a target (kindly provided by Dr. Ethel Cesarman, Cornell University). The IFA test was performed using the procedure described by Lennette et al. [1996] with minor modifications. Briefly, $5 \times 10^{5}$ cells $/ \mathrm{ml}$ were stimulated with tetra decanoyl phorbol acetate (TPA, 20 
$\mathrm{ng} / \mathrm{ml}$, Sigma, St. Louis, MO) for $72 \mathrm{hr}$ in culture medium (90\% RPMI 1640, 10\% fetal calf serum, $100 \mathrm{U} / \mathrm{ml}$ penicillin $\mathrm{G}$, and $100 \mu \mathrm{g} / \mathrm{ml}$ streptomycin). Two different lab technicians verified the IFA from each specimen at 1:40 dilution. To exclude false positive results due to background staining, all positive plasma were re-tested with BJAB cells (an HHV-8 negative B lymphoma cell line).

The HIV-1 serological status was established using two rapid assays, Capillus (Trinity Biotech, Bray Co., Wicklow, Ireland) and Determine (Abbott Laboratories, Abbott Park, IL), following the manufacturers' suggested procedures. Plasma that tested positive by a Capillus assay was confirmed by a Determine assay and vice versa.

Testing for syphilis involved the rapid plasma reagin assay (RPR, Arlington Scientific, Inc., Springville, UT) and a (Treponema pallidum) hemaglutination assay using the Serodia ${ }^{\circledR}-$ TPHA kit (Fujirebio, Inc., Tokyo, Japan). To avoid reporting biological false positive reactions, active syphilis was not considered to be present unless both assays were reactive.

\section{Statistical Analyses}

Given the cross-sectional design of the study, point and period prevalence estimates for HHV-8 were calculated. Associations between risk factors and HHV-8 positive serology were assessed using two-tailed $X^{2}$-tests with continuity correction and a significance level of 0.05 . Odds ratios (OR) and $95 \%$ confidence intervals $(\mathrm{CI})$ were determined via univariate and multivariate analyses. Frequencies were calculated for categorical variables and means/standard deviations were calculated for continuous variables.

Univariate analyses of categorical variables were evaluated by $X^{2}$-test with $P$-values $<0.05$ being considered significant. An independent $t$-test was used when comparing continuous variables. Associations represented by OR and $P$-value were appraised for statistical significance either by $95 \% \mathrm{CI}$ and/or by the statistical tests. Multivariate logistic regression, with stepwise backward procedure, was performed to control potentially confounding factors (SAS version 8). CI were calculated based on coefficients and standard errors from the logistic model [Hosmer and Lemeshov, 1989]. In addition, approximate CI were provided for proportions [Rosner, 1990]. All covariates that had a significant univariate association with the outcome of interest were included in the regression model. A variable remained in the model if either the likelihood ratio test was significant $(P<0.05)$ or the estimates of the $\beta$ coefficients for other variables in the model changed by at least $10 \%$. Multivariate OR and $95 \%$ CI were used to quantify the relationships in estimates while $P$-values were calculated to imply the statistical significance. The regression model was evaluated further by Hosmer-Lemeshov goodness-of-fit $X^{2}$ test [Hosmer and Lemeshov, 1989].

\section{Results}

Characteristics of the Study Population

Of approximately 10,000 pregnant women who attended UTH clinics during the study period, 6,525 women were admitted to the labor ward with $92 \%$ of those being screened for participation in the study. Of 3,470 women who met specific study inclusion criteria, 310 (8.9\%) refused to participate in the study. The main reasons for refusal, from most frequent to least, were: need to consult husband, not interested, live too far away, involved in other studies, do not want to know the test results, fear blood drawing, and cannot afford for transportation to come back for study follow-up visits.

The socio-demographic characteristics of the study population $(n=3,160)$ are presented in Table 1 . The women's median age was 25 years of age (standard deviation of 5.3)

Table 1. Socio-Demographic Characteristics by Human Herpesvirus-8 (HHV-8) Status

\begin{tabular}{|c|c|c|}
\hline Variable & $\begin{array}{l}\text { Frequency } \\
(\mathrm{N}) \text { total }(\%)\end{array}$ & $\begin{array}{c}\text { HHV }-8^{\mathrm{a}} \text { positive/ } \\
\text { negative ( } \% \text { positive) }\end{array}$ \\
\hline \multicolumn{3}{|l|}{ Age } \\
\hline$<20$ years & $768(24.3)$ & $292 / 465(38.6)$ \\
\hline $20-22$ years & $694(22.0)$ & $276 / 407(40.4)$ \\
\hline $23-27$ years & $856(27.1)$ & $346 / 499$ (41.0) \\
\hline $28+$ years & $831(26.3)$ & $340 / 484(41.3)$ \\
\hline Not reported & $11(0.3)$ & $0 / 9(18.2)$ \\
\hline Total & $3,160(100.0)$ & $1,254 / 1,864$ \\
\hline \multicolumn{3}{|l|}{ Marital status } \\
\hline Partnered & $2,835(89.7)$ & $1,141 / 1,573(42.0)$ \\
\hline Single & $290(9.2)$ & $103 / 262(28.2)$ \\
\hline Not reported & $35(1.1)$ & $9 / 24(27.3)$ \\
\hline Total & $3,160(100.0)$ & $1,253 / 1,859$ \\
\hline \multicolumn{3}{|l|}{ Tribal identity } \\
\hline Bemba & $949(30.0)$ & $331 / 611(35.1)$ \\
\hline Ngoni & $1,381(43.7)$ & $593 / 770(43.5)$ \\
\hline Tonga & 415 (13.1) & $156 / 251(38.3)$ \\
\hline Other & $394(12.5)$ & $166 / 224(42.6)$ \\
\hline Not reported & $21(0.7)$ & $5 / 15(25.0)$ \\
\hline Total & $3,160(100.0)$ & $1,251 / 1,871$ \\
\hline \multicolumn{3}{|l|}{ Religion } \\
\hline Christians & $3,078(97.4)$ & $1,219 / 1,822(40.1)$ \\
\hline Non-Christians & $53(1.7)$ & $27 / 26(50.1)$ \\
\hline Not reported & $29(0.9)$ & $8 / 12(40.0)$ \\
\hline Total & $3,160(100.0)$ & $1,254 / 1,860$ \\
\hline \multicolumn{3}{|l|}{ Education } \\
\hline Primary ( $\leq 7$ years) & $1,719(55.2)$ & $717 / 987(42.1)$ \\
\hline Secondary ( $\geq 8$ years) & $1,393(44.8)$ & $517 / 850(37.8)$ \\
\hline Not reported & $48(1.5)$ & $11 / 22(33.3)$ \\
\hline Total & $3,160(100.0)$ & $1,245 / 1,859$ \\
\hline \multicolumn{3}{|l|}{ Occupation } \\
\hline Housewife & $2,481(78.5)$ & $1,004 / 1,435(41.2)$ \\
\hline Self-employed & $230(7.3)$ & $84 / 140(37.5)$ \\
\hline Student & $83(2.6)$ & $28 / 54(34.2)$ \\
\hline Other & $35(11.1)$ & $116 / 228(33.7)$ \\
\hline Not reported & $16(0.5)$ & $4 / 12(25.0)$ \\
\hline Total & $3,160(100.0)$ & $1,236 / 1,869$ \\
\hline \multicolumn{3}{|l|}{ Household income } \\
\hline $\mathrm{US} \$ \leq 20.00$ & $232(7.4)$ & 85/144 (37.1) \\
\hline US $\$ 20.00-50.00$ & $1,371(43.4)$ & $547 / 811(40.3)$ \\
\hline US $\$ \geq 50.00$ & $1,226(38.8)$ & $494 / 723(40.6)$ \\
\hline Not reported & $331(10.5)$ & $123 / 178(40.9)$ \\
\hline Total & $3,160(100.0)$ & $1,249 / 1,856$ \\
\hline
\end{tabular}

${ }^{a}$ Numbers do not count up to the cell denominator (frequency by variable category) due to missing values. 
with a range from 14 to 43 years of age. The vast majority $(91 \%)$ of the women reported partnered relationships (e.g., formal or common-law marriage) and the remainder was single. Approximately $80 \%$ were housewives, $7 \%$ were self-employed, $11 \%$ held odd jobs, and $2 \%$ were students. Given a mean number of five persons per household (range 1-25), half of the women reported a family income below the local poverty level of US \$50 per month. Approximately, one of two women had completed primary education (/7 years), while the remainder had either gone through grade $12(40 \%)$ or had some tertiary education $(5 \%)$. The women's median age at the time of their first sexual encounter was 16 years.

\section{Prevalence of HHV-8 and Socio-Demographic Characteristics}

For analytical purposes, the study recruitment period was divided into four testing intervals. The HHV-8 period prevalence was found to be stable, ranging from $38 \%$ to $42 \%$ in each testing interval. During the period from September to December 1998, 334 (41\%) tested positive, from January to June 1999, $302(40 \%)$ tested positive, from July 1999 to January 2000, 308 (42\%) tested positive, and from February to October 2000, 313 (38\%) tested positive. The overall prevalence was $40.2 \%$ for HHV-8 $(1,257 / 3,131 ; 95 \%$ CI $38.5-41.9)$ and $29.9 \%$ for HIV-1 (913/3,058; 95\% CI 28.2-31.5). Co-infection with both pathogens was not uncommon, $13.6 \%$ (426/ 3,131; 95\% CI 12.8-15.2). Moreover, HHV-8 positive women were more likely to be infected with HIV-1 than those who were HHV-8 negative ( $34 \%$ vs. $26 \%$; P < 0.0001 ; OR $1 / 41.5 ; 95 \%$ CI 1.2-1.7) (Table 2).

The proportion of HHV-8 positive women was stable $(39 \%-41 \%)$ across all age groups (Table I). The predominant tribal group, Ngoni (44\%), had the highest prevalence of HHV-8 (43\%) but the lowest prevalence of HIV-1 (28\%) when compared to other tribal groups. Women with primary education were more likely to be positive for HHV-8 (42\%), but less likely to be infected with HIV-1 (26\%) when compared with those who completed secondary and/or tertiary education (38\% for HHV-8 and $34 \%$ for HIV-1).

\section{Univariate Determinants of HHV-8 Infections}

Several variables were found to be associated with positive HHV-8 serology. Two of the well-defined risk behaviors for contracting sexually transmitted diseases, intravenous drug use and anal sexual intercourse, were practically non-existent $(0.9 \%$ and $0.4 \%$, respectively) in the study population.

HHV-8 positive status was found to associate with women's primary education, diagnosis of syphilis and genital warts, histories of STDs and genital ulceration, and positive serological test results for HIV-1 and T. pallidum. All variables, despite relatively low OR, showed statistical significance (Table 3); the highest risk estimate was associated with the diagnosis of genital warts $(\mathrm{OR}=$ 1.62; 95\% CI 1.2-2.2; P < 0.001).

\section{Independent Risk Predictors of HHV-8 Infection}

All variables from the univariate analyses were entered into multiple logistic regression models to identify independent predictors of HHV-8 positive serology. The detailed results are presented in Table 3. Additional analyses were performed to investigate whether regressed variables that had been eliminated by the statistical procedure should be reintroduced into the final models. The results indicated that none of the re-tested parameters either separately or together had any significant effect on the model's predictability and were not included in Table 3.

Of the seven risk factors found to associate with HHV-8 in the univariate analyses, only three variables:

primary education $(P=0.005 ;$ OR $1 / 41.2 ; 95 \%$ CI $1.1-1.4)$, diagnosis of genital warts $(P=0.01$; OR $1 / 41.5 ; 95 \% C I$ 1.1-2.0), and HIV-1 positive serology $(P<0.0001$; OR $=$ $1.4 ; 95 \%$ CI 1.2-1.7) demonstrated statistically significant association with HHV-8 positive status by multiple logistic regression analysis (Table 3). The risk estimates for diagnosis of genital warts and positive HIV-1 serology were slightly higher, as compared with similar univariate estimates. Of the women analyzed, $84 \%$ had at least one independent risk predictor for HHV-8 infection. Among the remaining 16\%, with no identifiable risk factors for HHV-8, $16 \%$ were HHV-8 infected, while $11 \%$ were HHV-8 negative. Suitability of the regression model in predicting HHV-8 infection was then evaluated by $X^{2}$ goodness-of-fit test. The results showed an excellent fit of the data in the model $\left(X^{2}=0.36\right.$; degrees of freedom $=$ 3; $P=0.95)$. The model correctly predicted $95 \%$ of HHV-8 positive women as the truly HHV-8 positive women, as per Hosmer-Lemeshov $X^{2}$ goodness-of-fit test.

Table 2. HHV-8 and HIV-1 Serological Status

\begin{tabular}{|c|c|c|c|c|}
\hline \multirow[b]{2}{*}{ HHV-8 } & \multicolumn{3}{|c|}{ HIV-1 } & \multirow[b]{2}{*}{ Total } \\
\hline & Positive & Negative & Missing $^{\mathrm{a}}$ & \\
\hline Positive & $426(33.9 \%)^{\mathrm{b}} 46.7 \%$ & $807(64.2 \%) 37.6 \%$ & $24(1.9 \%) 23.5 \%$ & $1,257(100 \%) 39.8 \%$ \\
\hline Negative & $487(26.0 \%) 53.3 \%$ & $1,338(71.4 \%) 62.4 \%$ & $49(2.6 \%) 48.1 \%$ & $1,874(100 \%) 59.3 \%$ \\
\hline Missing $^{\mathrm{a}}$ & - & - & $29,28.4 \%$ & $29(100 \%) 0.9 \%$ \\
\hline Total & $913(28.9 \%) 100.0 \%$ & $2,145(67.9 \%) 100.0 \%$ & $102(3.2 \%) 100.0 \%$ & $3,160(100.0 \%) 100.0 \%$ \\
\hline
\end{tabular}

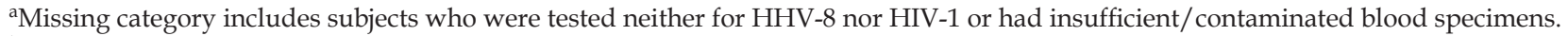

bercentages in parentheses represent percentage positive for HHV-8 and percentage in italics represents percentage positive for HIV. 


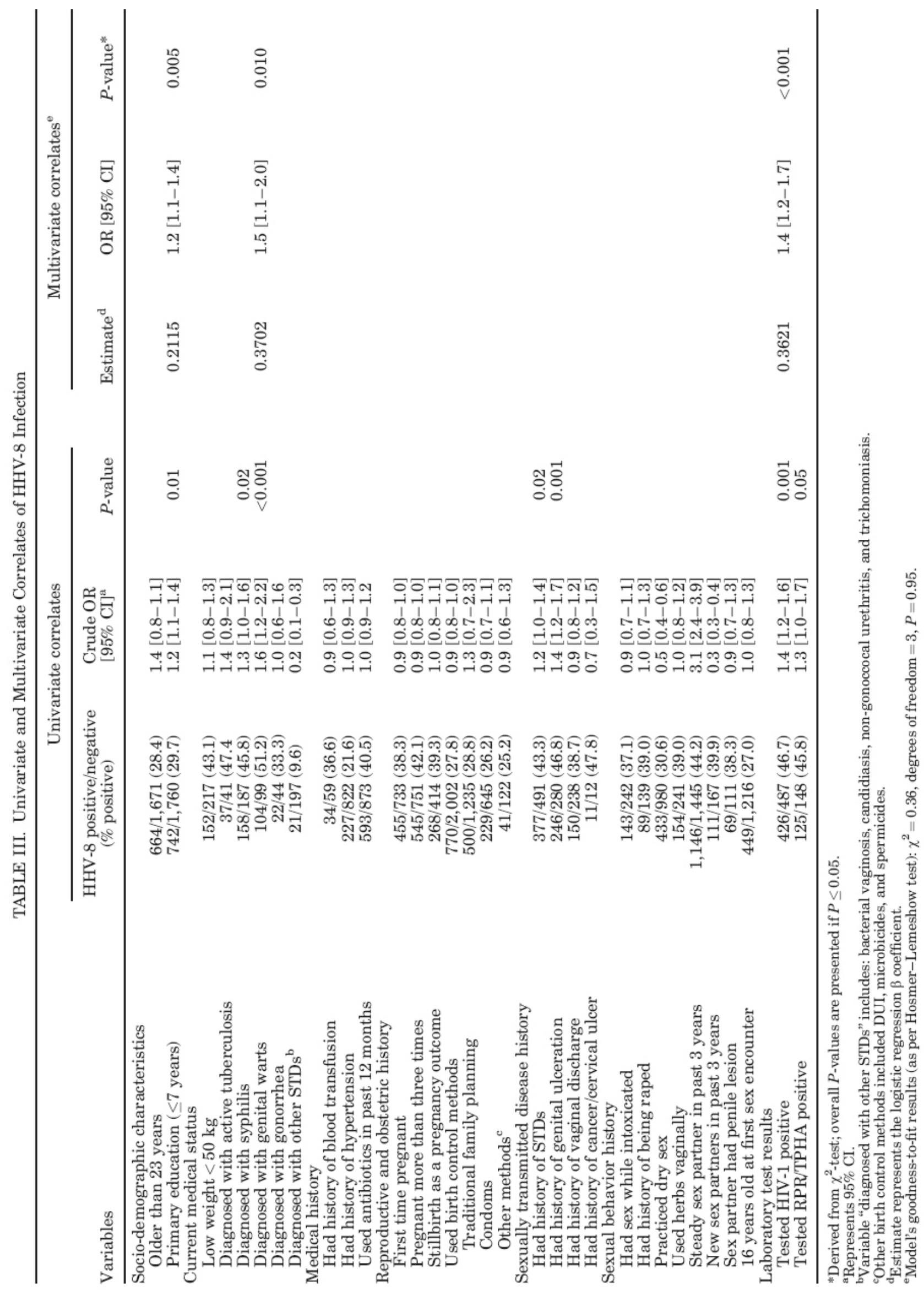




\section{Discussion}

This is the first study to report the comprehensive epidemiological characteristics of $\mathrm{HHV}-8$ infection in a large population of antenatal women in Zambia. The high prevalence of infection observed in the study population is consistent with the findings of similar studies of pregnant [Bestetti et al., 1998; de-The et al., 1999; Mantina et al., 2001] and non-pregnant women [Bestetti et al., 1998; He et al., 1998; Enbom et al., 1999; Rezza et al., 2000; Cook et al., 2002; DeSantis et al., 2002; Lavreys et al., 2003; Mbulaiteye et al., 2003] from other regions of Africa.

In our study, the high and relatively stable period prevalence of HHV-8 observed throughout the 2-year testing period indicates that this infection is well established in the study population. Furthermore, three risk factors including primary education, diagnosis of genital warts, and HIV-1 positive serology were independently associated with HHV-8 infection in the logistic regression analysis. Given that women's lower level of education ( $\leq 7$ years) was a predictor of HHV -8 infection, which was further correlated with lower socioeconomic status, one can speculate that poor living/environmental conditions (e.g., familial aggregation, household sanitary conditions) may play a role in non-sexual transmission of the virus, perhaps via saliva or nasal secretions [Blauvelt et al., 1997; Blackbourn et al., 1998; DeSantis et al., 2002]. Surprisingly, in our study, several sexual behavior variables, such as a past history of STD, including genital ulceration and diagnosis of syphilis, did not show a statistically significant relationship with HHV-8 in the multivariate model despite strong univariate correlations. Nevertheless, the diagnosis of genital warts emerged as the strongest predictor of HHV-8 seropositivity and may suggest sexual transmission of the virus. This assumption is supported by the results of recent studies, which documented an association between HIV-1, human papillomavirus (HPV), and genital warts [O'Farrell, 1999; Bleeker et al., 2002; Silverberg et al., 2002]. Our finding of an association between HIV-1 and HHV-8 infection in our population confirms previous reports [Martin et al., 1998; Hladik et al., 2003; Newton et al., 2003a] and the suggested epidemiological association of KS with HIV-1 [Sitas et al., 1997; Amir et al., 2001; Newton et al., 2003a]. However, there are contrary reports suggesting that there is no relationship between HIV-1 and HHV-8 infection [Baeten et al., 2002; DeSantis et al., 2002; Marcelin et al., 2002]. It is likely that these discrepancies are due to differences in cohort populations and the assays used for HHV-8 diagnoses. Our IFA-based serological assays were designed to detect both HHV-8 lytic and latent antigens. The detection of either one was considered sufficient criterion for a positive designation. Recently, we have developed a baculovirus-based recombinant antigen IFA and have found over $95 \%$ concordance between our original IFA and the insect-based IFA (unpublished data). Considering our large population size and the concordance between our serological assays, we believe that the observed correlation between HIV-1 and $\mathrm{HHV}-8$ infection in our studied population is valid. Even though there is no reported mechanism describing how HIV-1 facilitates HHV-8 transmission, or vice versa, it is possible that HIV-1 induced immunosuppression could enhance the susceptibility to HHV-8 infection or could increase the viral load in dually infected donors. HIV-1 infection could also be an indicator of a particular sexual behavior that is associated with the transmission of both HIV-1 and HHV-8. Despite high prevalence of both HHV-8 and HIV-1 infections, a relatively small proportion of women were found to be infected with both viruses. If the acquisition of these agents were independent events, it is possible that many of the dually HHV-8/ HIV-1 infected women acquired the HHV-8 virus, prior to becoming sexually active and then became coinfected with HIV-1 through the heterosexual contact, while the remainder (especially those infected with genital warts) could have contracted both HHV-8 and HIV-1 heterosexually. The fact that pregnant women were co-infected with both viruses represents a public health concern, as the simultaneous presence of multiple pathogens may facilitate progression of these diseases (e.g., AIDS and $\mathrm{KS}$ ) or transmission of other infectious agents (e.g., other herpesviruses and other STDs).

\section{Value and Limitations}

The cross-sectional design of this study provided a rapid method of risk estimation as compared with cohort studies. Its strength lies in the large number of study participants, the representative nature of the selected sample, the 2-year screening period, and the complexity of the data collected through structured interviews and medical record reviews. These attributes allowed us to investigate and characterize over 100 of the risk factors for HHV-8 infection that have not been well investigated by research reports from central sub-Saharan African countries, including Zambia.

We are aware, however, that the women's serological status and associated risk behaviors were evaluated not at the time of seroconversion, but at an undeterminable time point after initial infection. This might have misrepresented the associations. Since many variables were examined for our outcome of interest, it is possible that some proportion of our findings were due to chance as well. Thus, the temporal nature of associations could not be determined. In addition, whether the study results presented here can provide a definite answer as to whether the identified risk estimates for HHV-8 among antenatal women are the same as those in a general population of non-pregnant women of childbearing age in Lusaka, Zambia needs further investigation.

\section{Conclusions}

This is the first comprehensive, epidemiological assessment of HHV-8 infection in antenatal women in a central 
sub-Saharan African country. The independent association of HHV-8 with HIV-1 infection, genital warts, and women's lower level of education ( $\leq 7$ years) suggests that sexual as well as non-sexual transmission of HHV-8 occurs in Zambia and other HHV-8 endemic regions. This finding warrants further studies on virus transmission. It also suggests that HIV-1 infection in pregnant women and likely women in general is largely undiagnosed and certainly underreported. Since HHV-8 facilitates development of AIDS-associated KS, the HHV-8 prevalence and risk behaviors identified in this study could be utilized to identify specific population groups of pregnant women who are at increased risk for the development of KS.

\section{Acknowledgments}

We thank the study team involved in the field, in the laboratory, and in data collection. We appreciate the support of the University of Zambia, School of Medicine and the Ministry of Health in allowing us to conduct this study in the antenatal clinic in Lusaka. We also thank the Study Scientific Advisory Board at the University Teaching Hospital for their continued aid and scientific advice, and Dianna Wright for her assistance with preparation of the article. During the implementation phase of the study, Dr. Kankasa and Dr. Bhat were supported by training grants from the Fogarty International Center (D43 TW 00002) to the University of Miami and the University of Nebraska.

\section{References}

Amir H, Kaaya EE, Manji KP, Kwesigabo G, Biberfeld P. 2001. Kaposi's sarcoma before and during a human immunodeficiency virus epidemic in Tanzanian children. Pediatr Infect Dis J 20: 518-521.

Andreoni M, El-Sawaf G, Rezza G, Ensoli B, Nicastri E, Ventura L, Ercoli L, Sarmati L, Rocchi G. 1999. High seroprevalence of antibodies to human herpesvirus-8 in Egyptian children: Evidence of nonsexual transmission. I Natl Cancer Inst 91: 465-469.

Athale UH, Patil PS, Chintu C, Elem B. 1995. Influence of HIV epidemic on the incidence of Kaposi's sarcoma in Zambian children. J Acquir Immune Defic Syndr Hum Retrovirol 8: 96100.

Baeten JM, Chohan BH, Lavreys L, Rakwar JP, Ashley R, Richardson BA, Mandaliya K, Bwayo JJ, Kreiss JK. 2002. Correlates of human herpesvirus 8 seropositivity among heterosexual men in Kenya. AIDS 16: 2,073-2,078.

Bestetti G, Renon G, Mauclere P, Ruffie A, Mbopi Keou FX, Eme D, Parravicini C, Corbellino M, de The G, Gessain A. 1998. High seroprevalence of human herpesvirus-8 in pregnant women and prostitutes from Cameroon. AIDS 12: $541-$ 543.

Blackbourn DJ, Lennette ET, Ambroziak J, Mourich DV, Levy JA. 1998. Human herpesvirus-8 detection in nasal secretions and saliva. J Infect Dis 177: 213-216.

Blauvelt A, Sei S, Cook PM, Schulz TF, Jeang KT. 1997. Human Herpesvirus-8 infection occurs following adolescence in the United States. J Infect Dis 176: 771-774.

Bleeker MC, Hogewoning CJ, Van Den Brule AJ, Voorhorst FJ, Van Andel RE, Risse EK, Starink TM, Meijer CJ. 2002. Penile lesions and human papillomavirus in male sexual partners of women with cervical intraepithelial neoplasia. J Am Acad Dermatol 47: 351- 357.
Cannon MJ, Dollard SC, Smith DK, Klein RS, Schuman P, Rich JD, Vlahov D, Pellett PE. 2001. Blood-borne and sexual transmission of human herpesvirus 8 in women with or at risk for human immunodeficiency virus infection. N Engl J Med 344: 637-643.

Cattani P, Cerimele F, Porta D, Graffeo R, Ranno S, Marchetti S, Ricci R, Capodicasa N, Fuga L, Amico R, Cherchi G, Gazzilli M, Zanetti S, Fadda G. 2003. Age-specific seroprevalence of human herpesvirus 8 in Mediterranean regions. Clin Microbiol Infect 9: 274-279.

Challine D, Roudot-Thoraval F, Sarah T, Laperche L, Boisson B, Mauberquez S, Dubernet F, Rigot P, Lefrere F, Mercier B, Brossard Y, Rouet F, Girot R, Loiseau P, Girard D, Claquin J, Loty B, Lerable J, Mariotti M, Pawlotsky JM, Lefrere JJ. 2001. Seroprevalence of human herpes virus 8 antibody in populations at high or low risk of transfusion, graft, or sexual transmission of viruses. Transfusion 41: 1,120-1,125.

Cook RD, Hodgson TA, Waugh AC, Molyneux EM, Borgstein E, Sherry A, Teo CG, Porter SR. 2002. Mixed patterns of transmission of human herpesvirus- 8 (Kaposi's sarcomaassociated herpesvirus) in Malawian families. J Gen Virol 83: 1,613-1,619.

de Sanjose S, Marshall V, Sola J, Palacio V, Almirall R, Goedert JJ, Bosch FX, Whitby D. 2002. Prevalence of Kaposi's sarcomaassociated herpesvirus infection in sex workers and women from the general population in Spain. Int J Cancer 98: 155158.

de-The G, Bestetti G, van Beveren M, Gessain A. 1999. Prevalence of human herpesvirus 8 infection before the acquired immunodeficiency disease syndrome-related epidemic of Kaposi's sarcoma in East Africa. J Natl Cancer Inst 91: 1,8881,889 .

DeSantis SM, Pau CP, Archibald LK, Nwanyanwu OC, Kazembe PN, Dobbie H, Jarvis WR, Jason J. 2002. Demographic and immune correlates of human herpesvirus 8 seropositivity in Malawi, Africa. Int J Infect Dis 6: 266-271.

Eltom MA, Mbulaiteye SM, Dada AJ, Whitby D, Biggar RJ. 2002. Transmission of human herpesvirus 8 by sexual activity among adults in Lagos, Nigeria. AIDS 16: 2,473-2,478.

Enbom M, Tolfvenstam T, Ghebrekidan H, Ruden U, Grandien M, Wahren B, Linde A. 1999. Seroprevalence of human herpes virus 8 in different Eritrean population groups. J Clin $\mathrm{Vi}$ rol 14: 167-172.

Gao SJ, Kingsley L, Li M, Zheng W, Parravicini C, Ziegler J, Newton R, Rinaldo CR, Saah A, Phair J, Detels R, Chang Y, Moore PS. 1996. KSHV antibodies among Americans, Italians, and Ugandans with and without Kaposi's sarcoma. Nat Med 2: 925-928.

Grulich AE, Olsen SJ, Luo K, Hendry O, Cunningham P, Cooper DA, Gao SJ, Chang Y, Moore PS, Kaldor JM. 1999. Kaposi's sarcoma-associated herpesvirus: A sexually transmissible infection? J Acquir Immune Defic Syndr Hum Retrovirol 20: 387-393.

He J, Bhat G, Kankasa C, Chintu C, Mitchell C, Duan W, Wood C. 1998. Seroprevalence of human herpesvirus 8 among Zambian women of childbearing age without Kaposi's sarcoma (KS) and mother-child pairs with KS. J Infect Dis 178: 1,7871,790 .

Hladik W, Dollard SC, Downing RG, Kataaha P, Pellett PE, Karon JM, Mermin J, Lackritz EM. 2003. Kaposi's sarcoma in Uganda: risk factors for human herpesvirus 8 infection among blood donors. J Acquir Immune Defic Syndr 33: 206-210. 
Hosmer D, Lemeshov S. 1989. Applied Logistic Regression. New York: Wiley \& Sons, Inc. pp. 43-44.

Lavreys L, Chohan B, Ashley R, Richardson BA, Corey L, Mandaliya K, Ndinya-Achola JO, Kreiss JK. 2003. Human herpesvirus-8: Seroprevalence and correlates in prostitutes in Mombasa, Kenya. J Infect Dis 187: 359-363.

Lennette ET, Blackbourn DJ, Levy JA. 1996. Antibodies to human herpesvirus type 8 in the general population and in Kaposi's sarcoma patients. Lancet 348: 858-861.

Mantina H, Kankasa C, Klaskala W, Brayfield B, Campbell J, Du Q, Bhat G, Kasolo F, Mitchell C, Wood C. 2001. Vertical transmission of Kaposi's sarcoma-associated herpesvirus. Int J Cancer 94: 749- 752.

Marcelin AG, Grandadam M, Flandre P, Nicand E, Milliancourt C, Koeck JL, Philippon M, Teyssou R, Agut H, Dupin N, Calvez V. 2002. Kaposi's sarcoma herpesvirus and HIV-1 seroprevalences in prostitutes in Djibouti. J Med Virol 68: 164-167.

Martin JN, Ganem DE, Osmond DH, Page-Shafer KA, Macrae D, Kedes DH. 1998. Sexual transmission and the natural history of human herpesvirus 8 infection. N Engl J Med 338: 948-954.

Mbulaiteye SM, Pfeiffer RM, Whitby D, Brubaker GR, Shao J, Biggar RJ. 2003. Human herpesvirus 8 infection within families in rural Tanzania. J Infect Dis 187: 1,780-1,785.

Melbye M, Cook PM, Hjalgrim H, Begtrup K, Simpson GR, Biggar RJ, Ebbesen P, Schulz TF. 1998. Risk factors for Kaposi'ssarcomaassociated herpesvirus (KSHV/HHV-8) seropositivity in a cohort of homosexual men, 1981-1996. Int J Cancer 77: 543-548.

Moore PS, Chang Y. 1995. Detection of herpesvirus-like DNA sequences in Kaposi's sarcoma in patients with and without HIV infection. N Engl J Med 332: 1,181-1,185.

Newton R, Ziegler J, Bourboulia D, Casabonne D, Beral V, Mbidde E, Carpenter L, Parkin DM, Wabinga H, Mbulaiteye S, Jaffe H, Weiss R, Boshoff C. 2003a. Infection with Kaposi's sarcoma-associated herpesvirus (KSHV) and human immunodeficiency virus (HIV) in relation to the risk and clinical presentation of Kaposi's sarcoma in Uganda. Br J Cancer 89: 502-504.

Newton R, Ziegler J, Bourboulia D, Casabonne D, Beral V, Mbidde E, Carpenter L, Reeves G, Parkin DM, Wabinga H, Mbulaiteye S, Jaffe H, Weiss R, Boshoff C. 2003b. The seroepidemiology of Kaposi's sarcoma-associated herpesvirus (KSHV/HHV-8) in adults with cancer in Uganda. Int J Cancer 103: 226-232.

Nuvor SV, Katano H, Ampofo WK, Barnor JS, Sata T. 2001. Higher prevalence of antibodies to human herpesvirus-8 in HIV-infected individuals than in the general population in Ghana, West Africa. Eur J Clin Microbiol Infect Dis 20: 362364.

O'Farrell N. 1999. Increasing prevalence of genital herpes in developing countries: implications for heterosexual HIV transmission and STI control programmes. Sex Transm Infect 75: 377-384.
Olsen SJ, Chang Y, Moore PS, Biggar RJ, Melbye M. 1998. Increasing Kaposi's sarcoma-associated herpesvirus seroprevalence with age in a highly Kaposi's sarcoma endemic region, Zambia in 1985. AIDS 12: 1,921-1,925.

Pauk J, Huang ML, Brodie SJ, Wald A, Koelle DM, Schacker T, Celum C, Selke S, Corey L. 2000. Mucosal shedding of human herpesvirus 8 in men. $N$ Engl J Med 343: 1,369-1,377.

Regamey N, Cathomas G, Schwager M, Wernli M, Harr T, Erb P. 1998. High human herpesvirus 8 seroprevalence in the homosexual population in Switzerland. J Clin Microbiol 36: 1,784-1,786.

Renwick N, Dukers NH, Weverling GJ, Sheldon JA, Schulz TF, Prins M, Coutinho RA, Goudsmit J. 2002. Risk factors for human Herpesvirus-8 infection in a cohort of drug users in the Netherlands, 1985-1996. J Infect Dis 185: 1,808-1,812.

Rezza G, Tchangmena OB, Andreoni M, Bugarini R, Toma L, Bakary DK, Glikoutou M, Sarmati L, Monini P, Pezzotti P, Ensoli B. 2000. Prevalence and risk factors for human herpesvirus-8 infection in northern Cameroon. Sex Transm Dis 27: 159-164.

Rosner B. 1990. Fundamentals of Biostatistics. Boston: PWS-Kent. pp. 171-173.

Serraino D, Toma L, Andreoni M, Butto S, Tchangmena O, Sarmati L, Monini P, Franceschi S, Ensoli B, Rezza G. 2001. A seroprevalence study of human herpesvirus type 8 (HHV8) in Eastern and Central Africa and in the Mediterranean area. Eur J Epidemiol 17: 871-876.

Silverberg MJ, Ahdieh L, Munoz A, Anastos K, Burk RD, CuUvin S, Duerr A, Greenblatt RM, Klein RS, Massad S, Minkoff H, Muderspach L, Palefsky J, Piessens E, Schuman P, Watts H, Shah KV. 2002. The impact of HIV infection and immunodeficiency on human papillomavirus type 6 or 11 infection and on genital warts. Sex Transm Dis 29: 427-435.

Sitas F, Taylor L, Madhoo J, Cooper K, Carrara H, Boshoff C, Weiss RA. 1997. Occurrence of human herpes virus 8 in Kaposi's sarcoma and other tumours in South Africa. $S$ Afr Med J 87: 1,020-1,022.

Sitas F, Carrara H, Beral V, Newton R, Reeves G, Bull D, Jentsch U, Pacella-Norman R, Bourboulia D, Whitby D, Boshoff C, Weiss R. 1999. Antibodies against human herpesvirus 8 in black South African patients with cancer. N Engl J Med 340: 1,863-1,871.

Sosa C, Klaskala W, Chandran B, Soto R, Sieczkowski L, Wu MH, Baum M, Wood C. 1998. Human herpesvirus-8 as a potential sexually transmitted agentin Honduras. J Infect Dis 178: 547-551.

Sosa C, Benetucci J, Hanna C, Sieczkowski L, Deluchi G, Canizal AM, Mantina H, Klaskala W, Baum M, Wood C. 2001. Human herpesvirus 8 can be transmitted through blood in drug addicts. Medicina (B Aires) 61: 291-294.

Whitby D, Luppi M, Barozzi P, Boshoff C, Weiss RA, Torelli G. 1998. Human herpesvirus 8 seroprevalence in blood donors and lymphoma patients from different regions of Italy. J Natl Cancer Inst 90: 395-397. 